\title{
Remdesivir may not be a magic bullet for COVID-19 from pharmaceutical perspective
}

\author{
Xiaoxing Huang ${ }^{1}$, Xiuhua Ren ${ }^{2}$, Dong $\mathrm{Liu}^{2}$, and Zheng $\mathrm{He}^{2}$ \\ ${ }^{1}$ Wuhan University Zhongnan Hospital \\ ${ }^{2}$ Affiliation not available
}

May 26, 2020

\begin{abstract}
Coronavirus disease 2019 (COVID-19) caused by the severe acute respiratory syndrome coronavirus 2 (SARS-CoV-2) has become the global pandemic and caused hundreds of thousands of people died in the world, which is in urgent need to develop new drug therapy and pathogen progressive information. Although abundant anti-viral drugs has been directly practiced in some patients, there are no specific drug treatment due to the new SARS-CoV-2 virus, which cause great disaster and panic all over the world. Remdesivir has been recently a strong candidate for the treatment of COVID-19. Recently, due to the support of antiviral experiments in vitro and a case report by compassionate use of the drug, remdesivir has been a promising candidate treatment for the treatment of COVID-19. As a broad-spectrum anti-viral compound targeting the viral RNA dependent RNA polymerase, remdesivir has been shown to suppress the coronavirus, such as SARS-CoV and MERS-CoV. However, is remdesivir really a magic bullet for COVID-19, also a coronavirus? In this article, we first overview the general information about SARSCoV-2 and its potential suppressing drug remdesivir. Then, we carefully discussed the limitation with the remdesivir antiviral study, including the case report by compassionate use of remdesivir. Finally, from the pharmaceutical perspective we explored the anti-virus capability of remdesivir against different viruses to see whether it's a magic bullet for COVID-19. Therefore, this paper provides crucial evidence and objective theoretical basis on remdesivir to cure COVID-19 infections.
\end{abstract}

\section{Key words:}

COVID-19, SARS-CoV-2, Remdesivir, Pharmaceutical perspective

Recently, the new type of "2019 Novel Coronavirus" (COVID-19) broke out in Wuhan, China, which rapidly became a pandemic threat to the whole world. The COVID-19 is caused by a previously unknown pathogen named severe acute respiratory syndrome-related coronavirus-2 (SARS-CoV-2), which is the seventh newly discovered coronavirus strain[1]. According to the World Health Organization (WHO) statistics, COVID-19 has now taken over many countries around the world, which brings the number of infections worldwide to more than 3 million and the death toll to more than 260,000. COVID-19 had a devastating impact on all sectors of the world. More seriously, there is no specific drug to treat the disease because it's a new virus. But there were similar outbreaks of coronavirus infection in 2003 and 2005 called SARS and MERS, respectively[2]. Both COVID-19 and SARS belong to the coronavirus family, and COVID-19 seems not to be very different from SARS regarding its clinical features, so the lessons we learned from the SARS are the best weapons to face this new global threat[3].

Prevention of COVID-19 transmission is accompanied by an aggressive global search for therapeutic drugs. Remdesivir (Gilead Sciences, Inc) is the first antiviral drug to make it to the public eye, which has become the magic bullet the public has been waiting for. So, the news about remdesivir is also all over the internet, and it is difficult to tell true or false. But where did this medicine come from? 
As an adenosine nucleotide analogue pro-drug, remdesivir (GS-5734) shows broad-spectrum antiviral activity against many RNA viruses[4]. Remdesivir can inhibit the RNA virus through the targeting of the viral RNA dependent RNA polymerase (RdRp), and covalently incorporated into the primer strand at the first replicated base pair to terminate the chain elongation $[5,6]$. Coronaviruses (CoVs) are single-stranded RNA viruses that infect most animal hosts and human, such as severe acute respiratory syndrome coronavirus (SARS-CoV) in 2002 and Middle East respiratory syndrome coronavirus (MERS-CoV) in 2012[7]. Because of the unique CoV proofreading 3'-5' exoribonuclease (ExoN), most nucleoside analogues have been incapable of inhibiting $\mathrm{CoV}$ replication except remdesivir[8]. Remdesivir's use as a treatment for Ebola has made it an antiviral drug of global interest. In 2018, remdesivir was approved by the FDA to enter a phase 3 clinical trial to treat Ebola. However, in this clinical trial, remdesivir could reduce the death rate for Ebola patients to 50 percent, which were not as good as the other two antibody drugs[9]. So the clinical trial ended in failure and remdesivir faded from public view.

However, a recent outbreak of COVID-19 in Wuhan has put remdesivir on the altar, again. Firstly, on January 30, 2020, a case report entitled "First Case of 2019 Novel Coronavirus in the United States" published in $N$ Engl $J$ Med . The article reported the first case of "2019-nCoV" infection confirmed patient in the United States and described the identification, diagnosis, clinical course, and management of the case. After various treatments did not significantly improve the symptoms of the patient, clinicians pursued compassionate use of an investigational antiviral therapy "remdesivir". So, treatment with intravenous remdesivir (a novel nucleotide analogue prod-rug in development) was initiated on the evening of day 7 . Happily, on hospital day 8 (illness day 12), the patient's clinical condition was improved[10]. Then on February 4, Wuhan Institute of Virology found remdesivir (EC50 = $0.77 \mu \mathrm{M}$; CC50 > $100 \mu \mathrm{M}$; SI > 129.87) effectively inhibited the recently emerged 2019-nCoV in vitro[11]. Besides, in recent years before the COVID19 outbreak, there have been several studies reporting on remdesivir's treatment on the coronavirus of SARS and MERS $[12,13]$. Therefore, in view of that COVID-19 is coronaviruses and close to SARS, the remdesivir has become the hopes of all the world people to fight against the "2019-nCoV" infection. Meanwhile, the China Food and Drug Administration (CFDA) quickly approved Phase 3 clinical trials of the remdesivir through the green channel in Wuhan, China, which began on February 4 and expected to end on April 17.

However, could remdesivir be a magic bullet for the COVID-19 treatment? First let's look at the pharmacodynamics relevant studies of remdesivir.

Actually, before approved into Phase 3 clinical trials in China, only the above two articles have suggested the therapeutic effect of remdesivir on the COVID-19. After careful reading, we found the curative effect about remdesivir was controversial in this case report. Firstly, in this case report [10], the low cycle threshold (Ct) values (18 to 20 in nasopharyngeal specimens and 21 to 22 in oropharyngeal specimens) on illness day 4 suggest the high levels of "2019-nCoV" virus in these specimens, which gradually reduced with the progress of the time. On illness day 11, the high Ct values (33 to 34 in nasopharyngeal specimens and 36 to 40 in oropharyngeal specimens) suggest the low levels of "2019-nCoV" virus in these specimens, which prompts before remdesivir treatment most of the "2019-nCoV" virus were eliminated by the immune system (As shown in Fig 1). This from another level indicates that the therapeutic effect of remdesivir on COVID-19 virus is questionable and need be discussed, which is easily ignored by people. Secondly, in the research by Wuhan Institute of Virology [11], remdesivir (EC50 $=0.77 \mu \mathrm{M}$; CC50 $>100 \mu \mathrm{M}$; SI $>129.87$ ) could effectively inhibit the COVID-19 in vitro. This experiment only confirmed the remdesivir inhibition of COVID-19 short-term infection in vitro (2 hours), and no time-effect relationship of remdesivir inhibition was confirmed. Therefore, it is not sufficient to approve remdesivir for Phase 3 clinical trial based on these two studies. 


\begin{tabular}{|c|c|c|c|c|}
\hline Specimen & Illness Day 4 & Illness Day 7 & Illness Day 11 & Illness Day 12 \\
\hline Nasopharyngeal swab & & & & $\begin{array}{l}\text { Positive } \\
\text { (Ct, 37-40) }\end{array}$ \\
\hline Oropharyngeal swab & $\begin{array}{l}\text { Positive } \\
\text { (Ct, 21-22) }\end{array}$ & $\begin{array}{l}\text { Positive } \\
\text { (Ct, 32-33) }\end{array}$ & $\begin{array}{l}\text { Positive } \\
(C \mathrm{Ct}, 36-40)_{\mathrm{Tr}}\end{array}$ & $\begin{array}{l}\text { Negative } \\
\text { tment with }\end{array}$ \\
\hline Serum & Negative & Negative & Pending $\operatorname{Re}$ & desivir Pending \\
\hline Urine & NT & Negative & NT & NT \\
\hline Stool & NT & $\begin{array}{l}\text { Positive } \\
\text { (Ct, 36-38) }\end{array}$ & NT & NT \\
\hline
\end{tabular}

\section{Figure 1:PCR detection value of virus in patients infected with "2019-ncov" after hospitalization}

In fact, remdesivir was originally used to cure Ebola, which end up in failure in the Phase 3 clinical trials. Before the outbreak of the COVID-19, only no more than 5 articles were confirmed the drug treatment for coronavirus $[12,14,15]$, such as MERS-CoV, SARS-CoV , etc. In this few studies, we found that remdesivir is used to cure the coronavirus by early treatment or prophylactic outside the body or inside the animal. The relationship between the viral titer and time of the remdesivir was studied [12], the author observed maximal inhibition when remdesivir was added between $2 \mathrm{~h}$ preinfection and $2 \mathrm{~h}$ postinfection. These results indicate that even if remdesivir really has been successfully used in the treatment of COVID-19 in the end, it is best used to cure the coronavirus by early treatment or prophylactic. So, we can infer from these basic studies that remdesivir is not a magic bullet for COVID-19.

With the progress of the COVID-19 epidemic, two clinical trials results on remdesivir had been published. Patients with severe COVID-19 by compassionate use of remdesivir showed that the clinical improvement was observed in 36 of 53 patients (68\%) [16]. Unfortunately, this study lack ongoing randomized, placebocontrolled trials of remdesivir therapy. On 29 April, the Phase 3 clinical of remdesivir run in China announced that it had found no benefits from remdesivir when compared with a placebo in severe COVID-19 patients [17]. There are still many scholars believe that remdesivir is the antiviral hope against SARS-CoV-2 [18, 19]. In light of the current findings we need to look at this drug objectively and rationally.

Furthermore, from pharmaceutical perspective we objectively explore the therapeutic effects of the remdesivir. Studies showed that in primary human lung epithelial cell cultures, the drug half-maximum effective concentration (EC50) is $0.07 \mu \mathrm{M}$ for SARS-CoV and MERS-CoV, which is 10 times lower than that of COVID-19 [5]. This data indicates that the inhibitory effect of remdesivir on COVID-19 is lower than that of SARS and MERS. Besides, remdesivir inhibits Ebola replication in multiple relevant human cell types with EC50 values of 0.06 to $0.14 \mu \mathrm{M}$ [20]. The current remdesivir administration is based on the Phase 3 clinical trial of Ebola, which may need to be re-explored since there is a tenfold difference in EC50 between them. Unfortunately, we were unable to find the blood concentration data of remdesivir in humans. The above results suggest that we should treat the drug remdesivir cautiously and objectively, and remdesivir is not a magic bullet for COVID-19 from pharmaceutical perspective, at least for now.

Although, due to the large scale outbreak of the COVID-19, people were easy to panic and could not correctly understand these knowledge. With the focus on therapeutic efficacy, more and more clinical data of remdesivir will be available in the foreseeable future with urgent need. Accordingly, a clearer understanding of the clinical pharmacology and significance of remdesivir will break through the clouds to see the sky in the ongoing pandemic. In the meantime, we must look at any drug objectively and rationally, and remdesivir may not be a magic bullet for COVID-19. 


\section{Role of the funding source:}

No funding source for this study.

\section{Author contributions:}

Authors ZH and XH performed in the review design, interpretation and manuscript writing. Authors ZH and XR assisted to set up the title of the article and consult relevant literature. Authors ZH and DL provided critical revision of the manuscript for important intellectual content and were responsible for revising the full text.

\section{Conflict of interest}

No conflicts of interest are declared by the authors.

\section{Acknowledgment}

Not applicable.

\section{References}

1. Ostaszewski M, Mazein A, Gillespie ME, Kuperstein I, Niarakis A, Hermjakob H, Pico AR, Willighagen EL, Evelo CT, Hasenauer J, Schreiber F, Drager A, Demir E, Wolkenhauer O, Furlong LI, Barillot E, Dopazo J, Orta-Resendiz A, Messina F, Valencia A, Funahashi A, Kitano H, Auffray C, Balling R, Schneider R. COVID-19 Disease Map, building a computational repository of SARS-CoV-2 virus-host interaction mechanisms. Scientific data 2020; 7: 136.

2. Kawana A. SARS, MERS and coronavirus infections. Nihon rinsho Japanese journal of clinical medicine 2016; 74: 1967-72.

3. Petrosillo N, Viceconte G, Ergonul O, Ippolito G, Petersen E. COVID-19, SARS and MERS: are they closely related? Clinical microbiology and infection : the official publication of the European Society of Clinical Microbiology and Infectious Diseases 2020.

4. Lo MK, Feldmann F, Gary JM, Jordan R, Bannister R, Cronin J, Patel NR, Klena JD, Nichol ST, Cihlar T, Zaki SR, Feldmann H, Spiropoulou CF, de Wit E. Remdesivir (GS-5734) protects African green monkeys from Nipah virus challenge. Science translational medicine 2019; 11.

5. Brown AJ, Won JJ, Graham RL, Dinnon KH, 3rd, Sims AC, Feng JY, Cihlar T, Denison MR, Baric RS, Sheahan TP. Broad spectrum antiviral remdesivir inhibits human endemic and zoonotic deltacoronaviruses with a highly divergent RNA dependent RNA polymerase. Antiviral research 2019; 169: 104541.

6. Yin W, Mao C, Luan X, Shen DD, Shen Q, Su H, Wang X, Zhou F, Zhao W, Gao M, Chang S, Xie YC, Tian G, Jiang HW, Tao SC, Shen J, Jiang Y, Jiang H, Xu Y, Zhang S, Zhang Y, Xu HE. Structural basis for inhibition of the RNA-dependent RNA polymerase from SARS-CoV-2 by remdesivir. Science 2020.

7. Zaki AM, van Boheemen S, Bestebroer TM, Osterhaus AD, Fouchier RA. Isolation of a novel coronavirus from a man with pneumonia in Saudi Arabia. The New England journal of medicine 2012; 367: 1814-20.

8. Minskaia E, Hertzig T, Gorbalenya AE, Campanacci V, Cambillau C, Canard B, Ziebuhr J. Discovery of an RNA virus 3'->5' exoribonuclease that is critically involved in coronavirus RNA synthesis. Proc Natl Acad Sci U S A 2006; 103: 5108-13.

9. Mulangu S, Dodd LE, Davey RT, Jr., Tshiani Mbaya O, Proschan M, Mukadi D, Lusakibanza Manzo M, Nzolo D, Tshomba Oloma A, Ibanda A, Ali R, Coulibaly S, Levine AC, Grais R, Diaz J, Lane HC, Muyembe-Tamfum JJ, Group PW, Sivahera B, Camara M, Kojan R, Walker R, Dighero-Kemp B, Cao H, Mukumbayi P, Mbala-Kingebeni P, Ahuka S, Albert S, Bonnett T, Crozier I, Duvenhage M, Proffitt C, Teitelbaum M, Moench T, Aboulhab J, Barrett K, Cahill K, Cone K, Eckes R, Hensley L, Herpin B, Higgs E, Ledgerwood J, Pierson J, Smolskis M, Sow Y, Tierney J, Sivapalasingam S, Holman W, Gettinger N, 
Vallee D, Nordwall J, Team PCS. A Randomized, Controlled Trial of Ebola Virus Disease Therapeutics. The New England journal of medicine 2019; 381: 2293-303.

10. Holshue ML, DeBolt C, Lindquist S, Lofy KH, Wiesman J, Bruce H, Spitters C, Ericson K, Wilkerson S, Tural A, Diaz G, Cohn A, Fox L, Patel A, Gerber SI, Kim L, Tong S, Lu X, Lindstrom S, Pallansch MA, Weldon WC, Biggs HM, Uyeki TM, Pillai SK, Washington State -nCo VCIT. First Case of 2019 Novel Coronavirus in the United States. The New England journal of medicine 2020.

11. Wang M, Cao R, Zhang L, Yang X, Liu J, Xu M, Shi Z, Hu Z, Zhong W, Xiao G. Remdesivir and chloroquine effectively inhibit the recently emerged novel coronavirus (2019-nCoV) in vitro. Cell research 2020; 30: 269-71.

12. Agostini ML, Andres EL, Sims AC, Graham RL, Sheahan TP, Lu X, Smith EC, Case JB, Feng JY, Jordan R, Ray AS, Cihlar T, Siegel D, Mackman RL, Clarke MO, Baric RS, Denison MR. Coronavirus Susceptibility to the Antiviral Remdesivir (GS-5734) Is Mediated by the Viral Polymerase and the Proofreading Exoribonuclease. mBio 2018; 9.

13. Beigel JH, Nam HH, Adams PL, Krafft A, Ince WL, El-Kamary SS, Sims AC. Advances in respiratory virus therapeutics - A meeting report from the 6th isirv Antiviral Group conference. Antiviral research 2019; 167: 45-67.

14. Sheahan TP, Sims AC, Leist SR, Schafer A, Won J, Brown AJ, Montgomery SA, Hogg A, Babusis D, Clarke MO, Spahn JE, Bauer L, Sellers S, Porter D, Feng JY, Cihlar T, Jordan R, Denison MR, Baric RS. Comparative therapeutic efficacy of remdesivir and combination lopinavir, ritonavir, and interferon beta against MERS-CoV. Nature communications 2020; 11: 222.

15. Sheahan TP, Sims AC, Graham RL, Menachery VD, Gralinski LE, Case JB, Leist SR, Pyrc K, Feng JY, Trantcheva I, Bannister R, Park Y, Babusis D, Clarke MO, Mackman RL, Spahn JE, Palmiotti CA, Siegel D, Ray AS, Cihlar T, Jordan R, Denison MR, Baric RS. Broad-spectrum antiviral GS-5734 inhibits both epidemic and zoonotic coronaviruses. Science translational medicine 2017; 9.

16. Grein J, Ohmagari N, Shin D, Diaz G, Asperges E, Castagna A, Feldt T, Green G, Green ML, Lescure FX, Nicastri E, Oda R, Yo K, Quiros-Roldan E, Studemeister A, Redinski J, Ahmed S, Bernett J, Chelliah D, Chen D, Chihara S, Cohen SH, Cunningham J, D'Arminio Monforte A, Ismail S, Kato H, Lapadula G, L'Her E, Maeno T, Majumder S, Massari M, Mora-Rillo M, Mutoh Y, Nguyen D, Verweij E, Zoufaly A, Osinusi AO, DeZure A, Zhao Y, Zhong L, Chokkalingam A, Elboudwarej E, Telep L, Timbs L, Henne I, Sellers S, Cao H, Tan SK, Winterbourne L, Desai P, Mera R, Gaggar A, Myers RP, Brainard DM, Childs R, Flanigan T. Compassionate Use of Remdesivir for Patients with Severe Covid-19. The New England journal of medicine 2020.

17. Yeming W, Dingyu Z, Guanhua D, Ronghui D, Jianping Z, Yang J, et al. Remdesivir in adults with severe COVID-19: a randomised, double-blind, placebo-controlled, multicentre trial. Lancet 2020; 10236, 1567-1578.

18. Reina J. [Remdesivir, the antiviral hope against SARS-CoV-2]. Revista espanola de quimioterapia : publicacion oficial de la Sociedad Espanola de Quimioterapia 2020.

19. Mullard A. Hints of hope with remdesivir. Nature reviews Drug discovery 2020.

20. Warren TK, Jordan R, Lo MK, Ray AS, Mackman RL, Soloveva V, Siegel D, Perron M, Bannister R, Hui HC, Larson N, Strickley R, Wells J, Stuthman KS, Van Tongeren SA, Garza NL, Donnelly G, Shurtleff AC, Retterer CJ, Gharaibeh D, Zamani R, Kenny T, Eaton BP, Grimes E, Welch LS, Gomba L, Wilhelmsen CL, Nichols DK, Nuss JE, Nagle ER, Kugelman JR, Palacios G, Doerffler E, Neville S, Carra E, Clarke MO, Zhang L, Lew W, Ross B, Wang Q, Chun K, Wolfe L, Babusis D, Park Y, Stray KM, Trancheva I, Feng JY, Barauskas O, Xu Y, Wong P, Braun MR, Flint M, McMullan LK, Chen SS, Fearns R, Swaminathan S, Mayers DL, Spiropoulou CF, Lee WA, Nichol ST, Cihlar T, Bavari S. Therapeutic efficacy of the small molecule GS-5734 against Ebola virus in rhesus monkeys. Nature 2016; 531: 381-5. 